\title{
Functional traits of two co-occurring sea urchins across a barren/forest patch system
}

\author{
D. Agnetta a , C. Bonaviri a,*, F. Badalamenti ${ }^{\text {b }}$, C. Scianna a ${ }^{\text {, S. Vizzini a }}{ }^{\text {, P. Gianguzza a }}{ }^{\text {a }}$ \\ a Dipartimento di Scienze della Terra e del Mare (DiSTeM), Università di Palermo, Via Archirafi, 22-90123 Palermo, Italy \\ b CNR-IAMC, Sede di Castellammare del Golfo, Via G. da Verrazzano 17, 91014 Castellammare del Golfo (TP), Italy
}

\section{A R T I C L E I N F O}

\section{Article history}

Received 15 December 2011

Received in revised form 27 August 2012

Accepted 31 August 2012

Available online 8 September 2012

\section{Keywords:}

Paracentrotus lividus

Arbacia lixula

Functional traits

Sea urchins feeding behavior

Stable isotopes

Alternative stable states

\begin{abstract}
A B S T R A C T
Temperate rocky reefs may occur in two alternative states (coralline barrens and erect algal forests), whose formation and maintenance are often determined by sea urchin grazing. The two sea urchin species Paracentrotus lividus and Arbacia lixula are considered to play a similar ecological role despite their differing morphological traits and diets. The patchy mosaic areas of Ustica Island, Italy, offer an ideal environment in which to study differences in the performance of $P$. lividus and $A$. lixula in barren versus forest states. Results show that the two sea urchin species differ in diet, trophic position, grazing adaptation, movement ability and fitness in both barren and forest patches. We confirmed herbivory in P. lividus and omnivory with a strong tendency to carnivory in A. lixula. When the sea urchin escape response to a predator was triggered, $P$. lividus responded faster in barren and forest patches. Forest patch restricted movement, especially in A. lixula (velocity in barren $\approx 10$-fold greater than in forest). A large Aristotle's lantern, indicative of durophagy, confirmed adaptation of $A$. lixula to barren state.
\end{abstract}

(c) 2012 Elsevier B.V. All rights reserved.

\section{Introduction}

Temperate rocky marine ecosystems may occur alternatively as algal forest or barren, the latter being dominated by sea urchins and encrusting organisms (Beisner et al., 2003; Graham, 2004; Knowlton, 2004; Palumbi et al., 2008; Scheffer et al., 2001; Suding et al., 2004). These alternative states are dynamic, and environmental perturbations (e.g. variations in the abundance of sea urchin predators, outbreaks of disease among sea urchins, destructive harvesting of benthic organisms, deterioration of water quality, storms etc.) can trigger one state to switch to the other (Bonaviri et al., 2009; Coleman et al., 2008; Fanelli et al., 1994; Gianguzza et al., 2011; Sala et al., 1998; Steneck et al., 2002). The transition between forest and barren is usually not homogeneous, and is often characterized by a patchy intermingled mosaic of the two states (Bulleri and Benedetti-Cecchi, 2006; Hereu et al., 2008; Sala et al., 1998; Watson and Estes, 2011). During the transition, sea urchin abundance and species composition vary greatly in patches, and their grazing activity likely affects their stability, ultimately determining the shift of the whole system toward one of the two stable states (barren vs forest) (Konar and Estes, 2003; Watson and Estes, 2011).

In Mediterranean rocky infralittoral systems, Paracentrotus lividus and Arbacia lixula are the most abundant sea urchin species (Guidetti, 2006; Sala et al., 1998). These species are often considered to occupy the same trophic guild (Benedetti-Cecchi et al., 1998; Sala et al., 2012),

\footnotetext{
* Corresponding author. Tel.:+39 09123862857; fax: + 3909123891847. E-mail address: chiabon@libero.it (C. Bonaviri).
}

but their distribution differs between algal states. In forests P. lividus is by far more frequent and abundant than $A$. lixula, which is absent or very rare (Gianguzza et al., 2010; Guidetti and Dulčić, 2007). At low densities, $P$. lividus becomes cryptic, hiding in crevices, feeding near its refuge and creating little barren patches, or "gardens" (Verlaque, 1987; Benedetti-Cecchi and Cinelli, 1995; Hereu, 2006). At high densities, P. lividus switches from cryptic to active grazing, creating large patches devoid of erect algae (Kempf, 1962; Sala and Zabala, 1996; Verlaque, 1987). In contrast, A. lixula reaches high densities only in barrens (Guidetti and Dulčić, 2007; Micheli et al., 2005; Privitera et al., 2011) where it plays a leading role in maintaining the substrata free of new benthic settlers (Bonaviri et al., 2011; Bulleri et al., 1999). It remains unclear whether the scarcity of $A$. lixula in the forest state results from its preference for encrusting algae, which are abundant in the barren state, or from its inability to move and penetrate thick algal canopies.

The two urchin species differ morphologically. P. lividus has shorter and denser spines than A. lixula and more extendible tube feet (Gianguzza et al., 2010; Guidetti and Mori, 2005; Santos and Flammang, 2005, 2007). These features potentially make P. lividus better adapted to penetrate, climb, and knock down the erect algae thalli in forest patches as a result of their superior mobility.

The Aristotle's lantern is larger in A. lixula than in P. lividus (Fernandez and Boudouresque, 1997) suggesting an adaptation in A. lixula to feed on crustose algae (i.e.: durophagy, sensu Hagen, 2008). Accordingly, gut content analysis indicates a strong feeding preference for encrusting corallines by A. lixula, in contrast with fleshy algae by P. lividus (Privitera et al., 2008 and reference therein). Moreover, some demonstrated larger lantern size (which indicates an increasing ability to scrape) and lower 
gonad somatic index values (a stress response, impairing fitness) in sea urchins inhabiting food-limited habitats, such as the barren, relative to those inhabiting habitats with abundant food, such as forest algae (Agatsuma et al., 2005; Bayed et al., 2005; Brady and Scheibling, 2006; Brewin et al., 2000; Byrne, 1990; Fernandez and Boudouresque, 1997; Konar and Estes, 2003; Levitan, 1992; Sànchez-España et al., 2004).

No experimental studies have specifically tested whether diet preference and movement capability can explain the different distribution and fitness of urchin species in barren and forest states.

At Ustica Island, a transitional phase with a patchy mosaic pattern of barren and forest occurred in 2009, providing an excellent opportunity to study the functional traits of $A$. lixula and P. lividus in different states, minimizing the bias associated with natural spatial and temporal variability. With the aim of better understanding the potential role of these two species in shaping communities, we analyzed, for each state and species: (a) gut contents and $\delta^{13} \mathrm{C}$ and $\delta^{15} \mathrm{~N}$ signatures, to assess diet and trophic positions; (b) lantern size, to estimate functional adaptation to durophagy; (c) movement ability and (d) gonadic mass to assess fitness. We predicted: (a) different diets for P. lividus and A. lixula in both forest and barren patches, with a preference for erect algae in the former species and for crustose algae in the latter; (b) larger lantern and (c) reduced movement ability in A. lixula and (d) small gonadic mass of $P$. lividus and A. lixula in barren and forest, respectively, resulting from the absence of their preferred food in these states.

\section{Materials and methods}

\subsection{Study area}

The Ustica Island MPA is located in southwest Italy. It was established in 1986 on a small volcanic island $80 \mathrm{~km}$ off the northern coast of Sicily, covering 16,000 ha, of which 65 are devoted to the no-take area along the northwestern part of the island (Zone "A," Fig. 1). The bottom of the no-take zone is an extensive rocky platform of gentle slope characterized by high structural complexity, which varies widely at spatial scales from centimeters to decimeters. Unlike other Mediterranean MPAs, the Ustica infralittoral zone developed in barren after protection enforcement (Gianguzza et al., 2006; Riggio and Milazzo, 2004) and until 2007 sea urchins, P. lividus and A. lixula, and encrusting corallines such as Lithophyllum spp., Pseudolithophyllum expansum, Lithothamnium spp., Mesophyllum coralloides dominated the bottom. In recent years, starfish predation reduced sea urchin abundance (Bonaviri et al., 2009; Di Trapani, 2011; Gianguzza et al., 2009a,b), likely promoting the flourishing of erect macroalgae (Agnetta et al., 2010; Gianguzza et al., 2010),forming a landscape of patches of tens of meters in diameter interspersed with barren, dominated by encrusting algae, or forest, dominated by erect algae.

The study was carried out during the second half of July 2009 on rocky reefs 3 to $6 \mathrm{~m}$ deep on the western side of Ustica Island
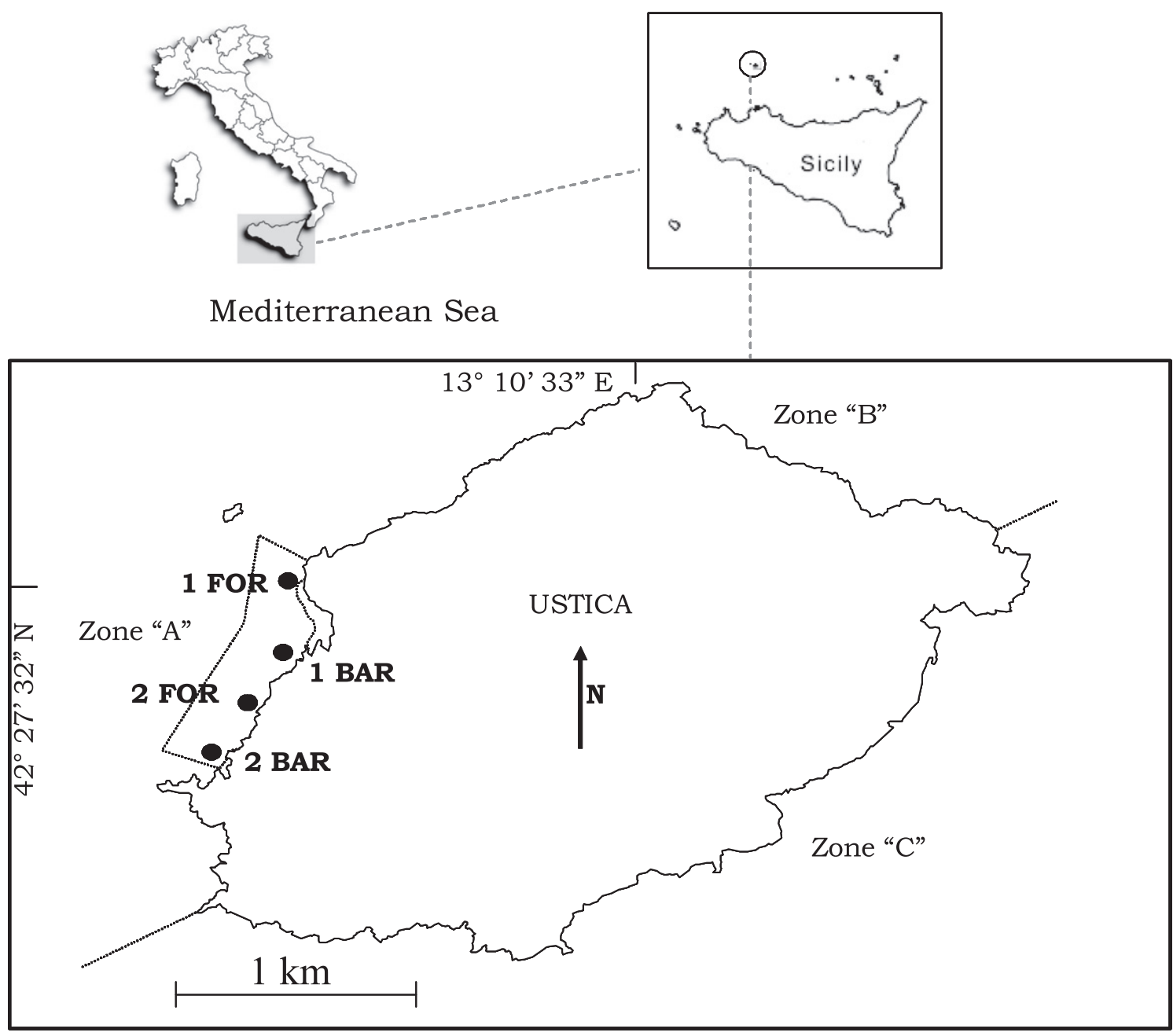

Fig. 1. Map of Ustica Island and sampling patches $(1,2)$ of each state (forest, FOR; barren, BAR). 
(Fig. 1). We selected four random patches (two characterized by barren and two by forest), each $200 \mathrm{~m}$ apart, from a set of patches with similar orientation $\left(270^{\circ}-275^{\circ}\right)$, water motion (Sunseri, 1995), and topography.

\subsection{Preliminary survey}

A preliminary survey was conducted in order to characterize benthic assemblage and urchin biomass in forest and barren patches. Benthic assemblages were assessed by superimposing a grid of 25 equal-sized small squares (each of them representing $4 \%$ of the total surface of each image) using digital image of each $400 \mathrm{~cm}^{2}$ area. The percent cover of each taxa was quantified in all the small quadrats by assigning a score between 0 (no presence) and 4 (total cover) to each taxa observed. Values of each small quadrat were added to obtain the final percentage of the entire quadrat (Chiantore et al., 2008). We placed 10 replicate quadrants randomly in each patch. In order to assess the organisms present beneath the algal forest canopy (hypo-strata), we photographed the replicates ( $n=10$ in each patch) after cutting all the erect algae present. Sea urchin biomass was calculated from the diameter and density of sea urchins in the field (see Cardona et al., 2007) based on the equation: $W=0.002 \times\left(D^{2.59}\right)\left(r^{2}=0.98\right)(W$ : weight in grams, $D$ : test diameter in millimeters) previously extrapolated from a sub-sample of individuals ( $n=50$ in each patch) of both $P$. lividus and A. lixula. Densities of both P. lividus and A. lixula were independently estimated in the field by visual counts within quadrats randomly located in each patch $\left(1 \mathrm{~m}^{2} ; n=10\right)$.

Benthic assemblages (PERMANOVA; $P(\mathrm{MC})=0.002 ; F_{1,36}=116.24$ ) and biomass of sea urchins (ANOVA species $\times$ state $P=0.025 ; F_{1}, 72=$ 37.86) differed significantly between barren and forest patches. Principal coordinates analysis (PCO, Appendix Fig. A1) showed that coralline algae and massive colonial and solitary invertebrates were associated with the barren patches, whereas erect algae like leathery macrophytes and corticated foliose were associated with forest (PCO1 89.7\%). Cover of crustose algae and leathery macrophytes significantly contributed to dissimilarity between barren and forest states (SIMPER, Appendix Table A1). Massive colonial (McA) and sessile invertebrates (SA) were significantly more abundant in the barren, even when we only detected a state effect for $\operatorname{McA}\left(F_{(1,39)}=121 ; p<0.009\right)$. Biomass of $P$. lividus was significantly higher in barren (mean \pm SD: $113.77 \pm 17.03$ ) than in forest patches $(35.32 \pm 8.96)$. Similarly, the biomass of $A$. lixula was significantly greater in barren $(123.67 \pm 15.60)$ than in forest $(8.75 \pm 3.44)$ areas.

\subsection{Sampling design}

In order to test for differences between the two sea urchin species in barren and forest patches in gut content, isotopic signatures $\left(\delta^{13} \mathrm{C}\right.$ and $\delta^{15} \mathrm{~N}$ ), lantern index (LI) and movement ability, we utilized a sampling design with three factors. We treated "Species" (Sp), as a fixed variable with two levels (A. lixula and P. lividus); "State" (St) as fixed and with two levels (barren and forest), and "Patch" (Pa) as random and nested in "State" with two levels $\left(\mathrm{P}_{1}\right.$ and $\left.\mathrm{P}_{2}\right)$.

Given that the two species differ in gonadic size and maturity cycles (author's data unpublished), we tested for differences in gonadosomatic index (GSI) between barren and forest patches for the two sea urchins using a sampling design with only two factors: "State" (St) was treated as fixed with two levels (barren and forest) and "Patch" (Pa) as random and nested in "State" with two levels $\left(\mathrm{P}_{1}\right.$ and $\left.\mathrm{P}_{2}\right)$.

\subsection{Sampling procedures}

In order to analyse urchin diet, we collected six adult specimens of both species ( $>35-\mathrm{mm}$ test diameter) in each patch and dissected them as soon as possible in order to avoid gut evacuation. After dissection gut contents were immediately frozen. We later took at random two equal volumes of gut contents from each sample and placed them on a $2.5 \times 2.5-\mathrm{cm}$ grid in a Petri dish in order to evaluate the percent cover of each item through a binocular microscope. We then estimated the relative percent abundance of each gut item based on percent cover. This method allowed us to take into account the percent occurrence of the different food items and also their relative volume (Privitera et al., 2008). For the gut contents, we grouped animal and algal taxa a priori using the morpho-functional criteria outlined by Steneck and Dethier (1994) for algae and Jackson (1979) for animals (Table 1). We used morpho-functional criteria because we reasoned that size, shape and anatomy of prey (i.e. algae and sessile animals) control the ability of sea urchins to handle and ingest them (Steneck and Dethier, 1994). Moreover, the use of these groups could facilitate future comparisons at larger spatial and temporal scales. We were generally able to identify food items to genus level (Table 1), but when identification was not possible we used anatomical components (e.g. tissue, morphology) to place them in one of the morpho-functional groups. Completely digested material was not considered. All samples were standardized relative to total gut contents.

Table 1

Description of shared functional groups used in benthic and gut content analysis and trophic guilds for stable isotopes analysis.

\begin{tabular}{|c|c|c|}
\hline Groups & Gut content/benthic assemblage & Stable isotopes \\
\hline Crustose algae (CA) & Lithophyllum, Lithothamnium & Lithophyllum, Lithothamnium \\
\hline Filamentous algae (Fil) & Ceramium spp., Bryopsis spp., Spachelaria spp., Cladophora spp. & Ceramium spp., Bryopsis spp., Spachelaria spp., Cladophora spp. \\
\hline Foliose algae (Fol) & Anadyomene stellata, Flabellia petiolata & Anadyomene stellata \\
\hline Corticated foliose algae (CoFo) & Padina pavonica, Dictyopteris membranacea, Dictyota spp. & Dictyota spp. (CoFoF) and Padina pavonica (CoFoC) \\
\hline Corticated macrophyte (CoMa) & Laurencia spp., Stypocaulon scoparium & Laurencia spp. \\
\hline Leathery macrophyte (LM) & Cystoseira spp. & Cystoseira spp. \\
\hline Articulated calcareous Algae (ACA) & Corallina sp., Jania sp., Amphiroa rigida, Halimeda tuna & Liagora viscida, Amphiroa rigida \\
\hline Solitary animals (SA) & $\begin{array}{l}\text { Anthozoans such as Anemonia viridis, vermetids, polychaetes, } \\
\text { foraminiferans (gut) }\end{array}$ & \\
\hline Sheet-like colonial animals (ScA) & Such as encrusting bryozoans, didemnids & \\
\hline Massive colonial animals (McA) & $\begin{array}{l}\text { Sponges, anthozoans such as Cladocora caespitosa, } \\
\text { bryozoans such as Myriapora truncate }\end{array}$ & \\
\hline Tree-like colonial animals (TA) & Colonial stoloniferous, colonial hydroids & \\
\hline Particulate feeders (PF) & & Anemonia viridis, Aiptasia spp. \\
\hline Meso herbivores (MH) & & Cerithium spp., columbellidae \\
\hline Detritivores (DS) & & Sipunculids \\
\hline Crustaceans omnivores (CrOm) & & Calcinus tubularis and other small crustaceans \\
\hline Suspension feeders (SF) & & Vermetids, serpulids, stoloniferous \\
\hline Filter feeders (FF) & & Protula sp., Spirastella cuncatrix \\
\hline Rock (RK) & Denuded substrate (benthic assemblage) & \\
\hline Other animals (OA) & Animal fragments in the gut contents & \\
\hline
\end{tabular}


The diet of the two sea urchins was also investigated through stable isotope analyses $\left(\delta^{13} \mathrm{C}\right.$ and $\left.\delta^{15} \mathrm{~N}\right)$. While not providing the dietary resolution of gut content observation, stable isotope analysis produces an averaged measure, by time and space, of what has been assimilated. Five individuals of each adult $P$. lividus and $A$. lixula and their potential prey (five pieces of each algae and five individuals for each animal species) were hand-collected from all patches and separately sealed in plastic bags. Faunal specimens were sampled by slicing a small portion of the foot of Anemonia viridis and Aiptasia sp. and of sea urchins' lantern muscles (Tomas et al., 2006). For any other animal the whole body (excluding shell) was used. For the algae various pieces of thalli were used. Samples of sedimentary organic matter (SOM) were collected in $50 \mathrm{ml}$ plastic pumps from each patch $(n=5)$. Sediment samples were filtered through $0.45-\mu \mathrm{m} \mathrm{GF/F} \mathrm{filters} \mathrm{to} \mathrm{extract} \mathrm{the} \mathrm{particulate} \mathrm{portion.} \mathrm{Half} \mathrm{of} \mathrm{the} \mathrm{samples,}$ with the exception of sea urchin muscles, were washed with $2 \mathrm{~N} \mathrm{HCl}$ to remove inorganic carbonates and analysed for $\delta^{13} \mathrm{C}$. Given that the acid wash could alter $\delta^{15} \mathrm{~N}$ values (Tomas et al., 2006), untreated parts were used to analyse $\delta^{15} \mathrm{~N}$. All samples were rinsed with distilled water and dried at $60{ }^{\circ} \mathrm{C}$ ( $48 \mathrm{~h}$ approximately). Measurements of stable isotope abundances were performed using a continuous-flow isotope-ratio mass spectrometer (Thermo Delta Plus XP) coupled to an elemental analyser CHN (Thermo EA 11112). Experimental precision, based on the standard deviation of replicates of the internal standard, was $0.2 \%$ o for $\delta^{13} \mathrm{C}$ and $\delta^{15} \mathrm{~N}$. Isotope ratios were expressed relative to PeeDee Belemnite (PDB) standard for carbon and to $\mathrm{N}_{2}$ in air for nitrogen. Ratios were calculated as: $\delta X=\left[\left(R_{\text {sample }} / R_{\text {standard }}-1\right)\right] \times 1000$ where $X$ is ${ }^{13} \mathrm{C}$ or ${ }^{15} \mathrm{~N}$, and $R$ is the corresponding ratio of ${ }^{13} \mathrm{C} /{ }^{12} \mathrm{C}$ or ${ }^{15} \mathrm{~N} /{ }^{14} \mathrm{~N}$. With the aim of visualizing trophic relationships between sea urchins and their prey, tropho-dynamic diagrams were constructed by grouping the organisms into trophic guilds as derived from morpho-functional features and isotopic signatures (Table 1).

The lantern index (LI) (lantern height/test diameter) was calculated for six individuals ( $>35$-mm test diameter) of each species per patch. Lantern length and test diameter were measured with a calliper at $0.05-\mathrm{mm}$ precision according to Levitan $(1991,1992)$. Wet gonado-somatic index (GSI) (gonad wet weight/total body wet weight) was calculated for the same individuals.

In order to measure the movement ability of the two species, we used the escape response of sea urchins induced by M. glacialis. Although this method measures the maximal locomotory performance of sea urchins under extreme circumstances, it facilitates a comparison of the movement ability of species in different substrata directly in the field, without manipulation of individuals. Moreover, no others alternative stimuli have been described in literature. The variable measured was the route covered by the sea urchins after contact with $M$. glacialis, which affects $P$. lividus and A.lixula urchins in that they immediately extend and open their globiferous pedicellariae (activation), lower their spines and flee from the point of contact. The route covered by six individuals of each species in five minutes was measured with a thin chain, in both barren and forest patches for a total of 48 replicates. Replicates were scattered, tens of meters apart, in the southern part of Ustica, where M. glacialis is abundant and benthic assemblage is similar to the " $\mathrm{A}$ " zone (Agnetta et al., 2010; Gianguzza et al., 2009a,b).

\subsection{Data analysis}

Gut contents were analyzed by distance-based permutational multivariate analysis of variance (PERMANOVA) (Anderson, 2001). The analysis was computed on a similarity matrix among samples, obtained by applying the Bray-Curtis index on the square root-transformed percentage of each animal and algal morpho-functional group of gut contents. Where appropriate, pair-wise tests (at $\alpha=0.05$ ) were used as a posteriori check of significant effects.

The untransformed isotopic signatures of $\delta^{13} \mathrm{C}, \delta^{15} \mathrm{~N}$ and the transformed $\operatorname{Ln}(X+1)$ distance covered by sea urchins were analyzed by ANOVA (Underwood, 1997) after checking for homogeneity of variances using Cochran's $C$ test. Student-Newman-Keuls (SNK) tests (at $\alpha=0.05$ ) were used, where appropriate, for a posteriori comparisons of the means (Underwood, 1997; Winer et al., 1991). Untransformed lantern and gonadosomatic indices values, resembled by Euclidean distance, were both analyzed by ANCOVA in relation to sea urchin size (test diameter) or total weight, respectively (see Ebert et al., 2011).

In order to assess the contributions of each trophic guild (Table 1) and SOM to the assimilated diet of sea urchins, linear mixing models were used. We examined all possible combinations of each source contribution (0-100\%) in small increments of $1 \%$ and tolerance of 0.1 to 0.5 as recommended by Phillips and Gregg (2003). Enrichments of 1.3 for carbon and 2.2 for nitrogen were considered to correct for isotope fractionation across trophic levels. In particular, we based our fractionation parameters on recommended estimates by McCutchan et al. (2003), for carbon (type of tissue analysed) and nitrogen (type of consumer diet, respectively. Mixing models were carried out using Iso-Source software version 1.3.1 (Phillips and Gregg, 2003). The trophic level of both sea urchins was calculated according to the equation developed by Hobson and Welch (1992): $\mathrm{TL}=1+(\mathrm{Nm}-\mathrm{Nb}) / \mathrm{TE}$, where $\mathrm{TL}=$ trophic level of the species, $\mathrm{Nm}=$ mean $\delta^{15} \mathrm{~N}$ value of the species, $\mathrm{Nb}=$ average basis $\delta^{15} \mathrm{~N}$ value of producers (algae) and TE $=$ trophic enrichment factor (see Section 2.2).

\section{Results}

\subsection{Gut contents}

Gut contents analysis revealed a diet dominated by crustose algae for A. lixula and by erect fleshy algae for $P$. lividus (Fig. 2). The diet composition of the two species differed significantly in both states. The gut contents of $A$. lixula were similar in barren and forest, but differed significantly for $P$. lividus (Table $2, \mathrm{Sp} \times \mathrm{St}$ interaction and pair-wise tests). $P$. lividus individuals collected in barren patches

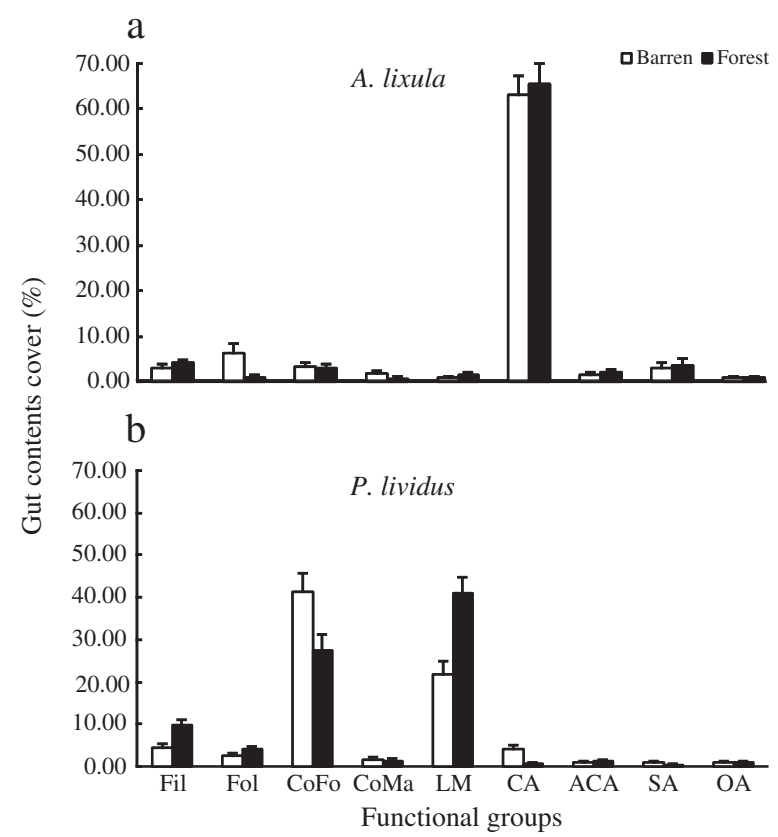

Fig. 2. Gut contents cover ( \pm S.E.) of sea urchin species in the two states. Fil = filamentous algae, $\mathrm{Fol}=$ foliose algae, $\mathrm{CoFo}=$ corticated foliose algae, $\mathrm{CoMa}=$ corticated macrophyte algae, $\mathrm{LM}=$ leathery macrophyte, $\mathrm{CA}=$ crustose algae, $\mathrm{ACA}=$ articulated calcareous algae, $\mathrm{SA}=$ solitary animal, $\mathrm{OA}=$ other animal. 
Table 2

Results of PERMANOVA testing for differences in sea urchin gut content cover considering the fixed factors "Species" with two levels (P. lividus and A. lixula) and "State" with two levels (barren and forest) and the random factor "Patch" (Pa) nested in "State" with two levels $\left(\mathrm{P}_{1}\right.$ and $\left.\mathrm{P}_{2}\right)$.

\begin{tabular}{llrrlll}
\hline Source & $d f$ & \multicolumn{1}{l}{ MS } & Pseudo- $F$ & $P($ perm $)$ & Unique perms & $P(\mathrm{MC})$ \\
\hline Species (Sp) & 1 & $39,085.0$ & 1568.80 & 0.03 & 713 & 0.00 \\
State $(\mathrm{St})$ & 1 & 519.7 & 0.73 & 1.00 & 3 & 0.56 \\
Patch (Pa) (St) & 2 & 709.7 & 1.74 & 0.12 & 9944 & 0.13 \\
$\mathrm{Sp} \times \mathrm{St}$ & 1 & 1498.5 & 60.15 & 0.04 & 798 & 0.00 \\
$\mathrm{Sp} \times \mathrm{Pa}(\mathrm{St})$ & 2 & 24.9 & 0.06 & 0.96 & 9951 & 0.96 \\
Res & 40 & 406.91 & & & & \\
Total & 47 & & & & & \\
\hline
\end{tabular}

contained corticated foliose algae, whereas those coming from forest patches had ingested mostly leathery macrophyte (Fig. 2).

\subsection{Stable isotopes}

Mean values of $\delta^{13} \mathrm{C}$ and $\delta^{15} \mathrm{~N}$ significantly differed between the two sea urchin species, with $\delta^{13} \mathrm{C}$ and $\delta^{15} \mathrm{~N}$ values higher for A. lixula than P. lividus in both barren and forest patches (Table 3, Fig. 3, Table A2.

Mixing models (mean and 1st to 99th percentiles) indicated that CoFo (24\% $\pm 18 \%$; $0-75 \%)$, SOM $(18 \% \pm 14 \% ; 0-57 \%)$ and CoMa (26\% $\pm 10 \% ; 0.2 \%-48 \%)$ were the principal sources of carbon and nitrogen assimilated by P. lividus, followed by LM (16\% $\pm 9 \%$; $0-36 \%)$, while animal guilds such as $\mathrm{MH}$, DS and SF provided a minor contribution $(\approx 5 \%$ each). On the contrary, results showed animals as the main food assimilated by A. lixula; DS (sipunculids) provided $71 \% \pm$ $7 \%(55 \%-88 \%)$ of the carbon and nitrogen while the other animal guilds (SF, CrOm, MH and $\mathrm{PF}$ ) and calcareous algae (CA and $\mathrm{CoFoC}$ ) represented $\approx 5 \%$ each. The trophic level for A. lixula $(\mathrm{TL}=3.05)$ was about one point greater than that for P. lividus $(\mathrm{TL}=2.18)$.

\subsection{Lantern index, movement ability and gonadosomatic index}

Lantern index was higher for A. lixula (mean \pm S.E.; $0.33 \pm 0.01$ ) than for P. lividus $(0.27 \pm 0.004)$, while State had no significant effect on this variable (Table 4). Although co-variable Size resulted significant, it never interacted with any of the considered factors (Table 4).

Although the two sea urchins were equally activated by the presence of the starfish in both patch types, the average distance covered by the two species was significantly different. The distance covered by P. lividus was higher than that of $A$. lixula in both barren and forest patches (Table 5; Fig. 4; SNK tests $p<0.01$ ). Moreover, A. lixula and P. lividus were faster in barren than in forest (Table 5; Fig. 4; SNK tests $p<0.01$ for $A$. lixula, $p<0.05$ for $P$. lividus)

GSI of $A$. lixula (mean \pm S.E.; $1.72 \pm 0.16)$ and P. lividus $(6.16 \pm 0.55)$ was not affected by the factor State (Table 6 ).

\section{Table 3}

Results of ANOVA testing for differences in sea urchins stable isotopes $\delta^{13} \mathrm{C}$ and $\delta^{15} \mathrm{~N}$ composition considering the fixed factors "Species" with two levels ( $P$. lividus and A. lixula) and "State" with two levels (barren and forest) and the random factor "Patch" (Pa) nested in "State" with two levels $\left(\mathrm{P}_{1}\right.$ and $\left.\mathrm{P}_{2}\right)$.

\begin{tabular}{|c|c|c|c|c|c|c|c|c|}
\hline \multirow[t]{2}{*}{ Source } & \multicolumn{4}{|c|}{$\delta^{13} \mathrm{C}$} & \multicolumn{4}{|c|}{$\delta^{15} \mathrm{~N}$} \\
\hline & $d f$ & MS & $F$ & $p$ & $d f$ & MS & $F$ & $\mathrm{p}$ \\
\hline Species (Sp) & 1 & 100.20 & 232.27 & 0.00 & 1 & 25.84 & 305.22 & 0.00 \\
\hline State (St) & 1 & 3.32 & 2.67 & 0.24 & 1 & 0.00 & 0.00 & 0.98 \\
\hline Patch (Pa) & 2 & 1.25 & 1.63 & 0.21 & 2 & 7.12 & 54.83 & 0.00 \\
\hline $\mathrm{Sp} \times \mathrm{St}$ & 1 & 0.33 & 0.76 & 0.47 & 1 & 0.02 & 0.20 & 0.70 \\
\hline $\mathrm{Sp} \times \mathrm{Pa}(\mathrm{St})$ & 2 & 0.43 & 0.56 & 0.57 & 2 & 0.08 & 0.65 & 0.53 \\
\hline Res & 32 & 0.77 & & & 32 & 0.13 & & \\
\hline Total & 39 & & & & & 39 & & \\
\hline
\end{tabular}

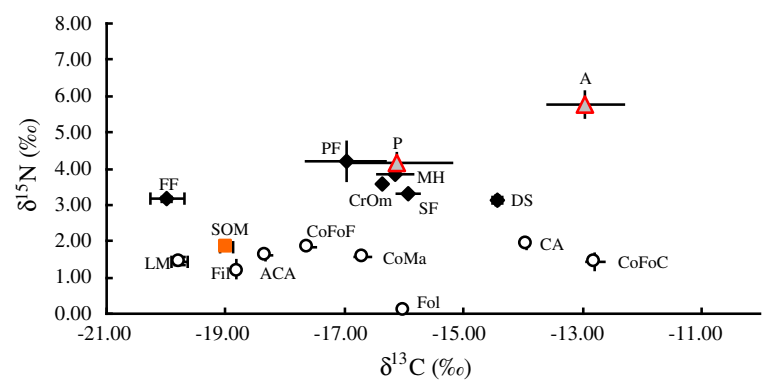

Fig. 3. Tropho-dynamic diagram of consumers and prey (pooled states and patches). $A=$ A. lixula, $\mathrm{P}=P$. lividus, $\mathrm{PF}=$ particulate feeders, $\mathrm{MH}=$ meso-herbivores, $\mathrm{DS}=$ detritivores, $\mathrm{CrOm}=$ crustaceans omnivores, $\mathrm{SF}=$ suspension feeders, $\mathrm{FF}=$ filter feeders, $\mathrm{LM}=$ leathery macrophyte, Fil =filamentous algae, ACA = articulated calcareous algae, CoFoF = corticated foliose flashy algae, $\mathrm{CoMa}=$ corticated macrophyte algae, Fol = foliose algae $\mathrm{CA}=$ crustose algae, $\mathrm{CoFoC}=$ corticated foliose calcareous algae, $\mathrm{SOM}=$ sedimentary or ganic matter.

\section{Discussion}

The functional traits of $P$. lividus and A. lixula were estimated during a transitional phase between forest and barren state. This phase was characterized by a patchy barren/forest system in which the two species co-occurred. Our results show that, regardless of the state of the patches where urchins were present, the two species were characterized by different: (1) diet, (2) trophic position, (3) lantern traits and (4) movement ability.

Previous manipulative experiments have highlighted the leading role of $A$. lixula in maintaining the barren state, but the relative role of the two species in the dynamic between forest and barren has generally been overlooked (Bonaviri et al., 2011). Indeed, the two species are often considered to belong to the same trophic guild and, therefore, to play the same role in shaping benthic communities (Sala et al., 2012). The results of this study, however, support the hypothesis that the two species belong to different trophic guilds and fulfil differing roles in the formation of barren.

The results of the gut contents and stable isotope $\left(\delta^{13} \mathrm{C}\right.$ and $\left.\delta{ }^{15} \mathrm{~N}\right)$ analysis clearly indicate that diet of the two species differ in both barren and forest states. In agreement with previous studies, the gut contents of the two sea urchins were dominated by algae, with a prevalence of fleshy erect algae in P. lividus and encrusting algae in A. lixula (Privitera et al., 2008 and references therein). In particular, gut contents did not always correspond to the benthic cover of each state: A. lixula largely consumed encrusting algae also in forest, where this group was scarcely present, and P. lividus ingested corticated foliose algae in barren, despite this group representing less than $5 \%$ of cover in this state. These findings suggest that the two species are somehow able to select different food sources.

The results of isotopic signatures did not match the gut contents outcomes and $\delta^{15} \mathrm{~N}$ showed that the trophic position occupied by A. lixula was higher than that of P. lividus. In particular, in A. lixula $\delta^{15} \mathrm{~N}$ signatures were higher than those expected for a herbivore. The mixing model confirmed that $A$. lixula mainly fed on several animal guilds. Contrarily, $\delta{ }^{15} \mathrm{~N}$ signatures of $P$. lividus were consistent with those expected for a herbivore. The mixing model indicated that this species fed principally on erect algae and that SOM played an important role in its diet. The mixing model also revealed a negligible contribution of invertebrates to the diet of $P$. lividus. From analysing results of both gut contents and isotopes, the two species should be considered omnivores with a strong tendency to carnivory for A. lixula and to herbivory in the case of $P$. lividus.

The apparent contradiction found between gut contents and isotopic signatures may have more than one plausible explanation. First, animal tissue is digested more rapidly than algae tissue (Fernandez and Boudouresque, 2000), animals are not ingested as a whole but only 
Table 4

Results of ANCOVA testing for differences in sea urchin lantern index considering the fixed factors "Species" with two levels (P. lividus and A. lixula) and "State" with two levels (barren and forest) and the random factor "Patch" (Pa) nested in "State" with two levels $\left(\mathrm{P}_{1}\right.$ and $\left.\mathrm{P}_{2}\right)$, considering the sea urchins size as covariate.

\begin{tabular}{llllll}
\hline Source & $d f$ & MS & Pseudo- $F$ & $P($ perm $)$ & Unique perms \\
\hline Size $(\mathrm{Si})$ & 1 & 0.026 & 50.76 & 0.00 & 9852 \\
Species $(\mathrm{Sp})$ & 1 & 0.018 & 22.22 & 0.04 & 7712 \\
State $(\mathrm{St})$ & 1 & 0.000 & 0.02 & 1.00 & 24 \\
Patch $(\mathrm{Pa})(\mathrm{St})$ & 2 & 0.001 & 0.98 & 0.40 & 9950 \\
$\mathrm{Si} \times \mathrm{Sp}$ & 1 & 0.000 & 0.52 & 0.47 & 9831 \\
$\mathrm{Si} \times \mathrm{St}$ & 1 & 0.001 & 1.33 & 0.27 & 9848 \\
$\mathrm{Sp} \times \mathrm{St}$ & 1 & 0.001 & 1.56 & 0.31 & 4253 \\
$\mathrm{Si} \times \mathrm{Pa}(\mathrm{St})$ & 2 & 0.000 & 0.29 & 0.74 & 9949 \\
$\mathrm{Sp} \times \mathrm{Pa}(\mathrm{St})$ & 2 & 0.001 & 1.29 & 0.30 & 9948 \\
$\mathrm{Si} \times \mathrm{Sp} \times \mathrm{St}$ & 1 & 0.000 & 0.52 & 0.48 & 9840 \\
$\mathrm{Si} \times \mathrm{Sp} \times \mathrm{Pa}(\mathrm{St})$ & 2 & 0.000 & 0.57 & 0.56 & 9956 \\
$\mathrm{Res}$ & 24 & 0.001 & & & \\
Total & 39 & & & & \\
\hline
\end{tabular}

parts are scraped off by the lantern (e.g. proboscid of sipunculids, fan of serpulids, etc.) and different types of algae are also characterized by different digestibility (Arafa et al., 2006; Frantzis and Gremare, 1992). Therefore, the proportion of animal and algal tissue ingested and rapidly digested by sea urchins might be underestimated by gut contents analysis. For example, leathery macrophyte, a slowly digested food, was the most abundant group in gut contents of $P$. lividus in forest, despite the fact that this group represents the least consumed food, as detected by the mixing model. Likewise, crustose algae were the most abundant item in the gut contents of A. lixula (60\%), although they represented less than $5 \%$ of the assimilated food (Cabral de Oliveira, 1991; Ganteaume et al., 1998; Knoepffler-Peguy et al., 1987; Otero-Villanueva et al., 2004). A second explanation could be that unidentifiable calcareous material, attributed to crustose algae, could actually derive from animal shells (such as suspension feeders like serpulids and meso herbivores). In accordance with this hypothesis, Wangensteen et al. (2011) individuated a large proportion of fragments of barnacle shells among the calcareous materials in the gut contents of A. lixula by using a scanning electron microscope.

The fact that $A$. lixula and $P$. lividus are two omnivores with a strong tendency to carnivory (i.e. A. lixula) and to herbivory (i.e. P. lividus) is in accordance with a recent study conducted in erect algae-dominated systems in the Western Mediterranean, which also reported that A. lixula consumes primarily animals but $P$. lividus mainly algae (Wangensteen et al., 2011). The fact that the two species also maintain these feeding habits in barren states undermines the assumption that these co-occurring species are two herbivores that, sharing the same ecological role, avoid competition with a selective interspecific partitioning of algae. We can now reasonably state that $A$. lixula and $P$. lividus have different diets and occupy distinct trophic positions; in other words, they do not compete for resources, neither in forest nor in barren states. These results are comparable to those found by Vanderklift et al. (2006) in

Table 5

Results of ANOVA testing for differences in sea urchin length covered route considering the fixed factors "Species" with two levels (P. lividus and A. lixula) and "State" with two levels (barren and forest) and the random factor "Patch" (Pa) nested in "State" with two levels $\left(\mathrm{P}_{1}\right.$ and $\left.\mathrm{P}_{2}\right)$.

\begin{tabular}{llcrl}
\hline Source & $d f$ & \multicolumn{1}{l}{ MS } & \multicolumn{1}{l}{ F } & \multicolumn{1}{l}{$p$} \\
\hline Species (Sp) & 1 & 632.75 & $16,166.82$ & 0.0001 \\
State (St) & 1 & 155.84 & 15.79 & 0.0579 \\
Patch (Pa) (St) & 2 & 0.9868 & 2.09 & 0.1373 \\
Sp $\times$ St & 1 & 125.99 & 3219.08 & 0.0003 \\
Sp $\times$ Pa (St) & 2 & 0.0039 & 0.01 & 0.9918 \\
RES & 40 & 0.4728 & & \\
TOT & 47 & & & \\
\hline
\end{tabular}

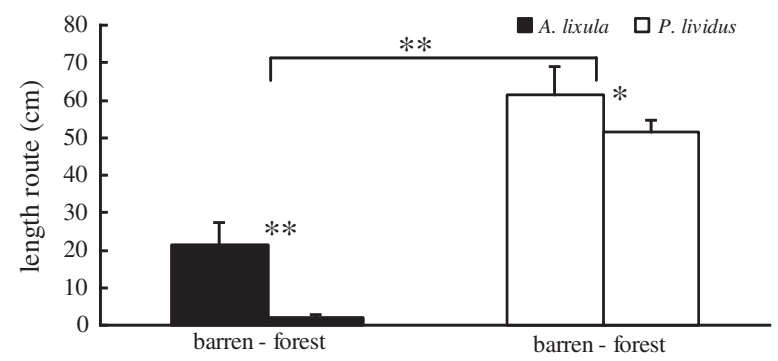

Fig. 4. Sea urchin length travelled route $(\mathrm{cm} \pm$ S.E. $)$ in the two studied states. SNK test: ${ }^{*} p<0.05 ;{ }^{* *} p<0.01$.

southwestern Australia, where the co-occurring sea urchin Centrostephanus tenuispinus and Phyllacanthus irregularis, commonly considered herbivores, exhibit an omnivorous habit tending to carnivory and are thus ecologically dissimilar to the almost exclusively herbivore Heliocidaris erythrogramma.

The carnivorous habit observed here for A. lixula fits well with other Arbacia species (Penchaszadeh, 1979; Silva et al., 2004) and other A. lixula populations. Cabral de Oliveira (1991) found that $71 \%$ of the guts of A. lixula collected from Brazil consisted of the cirriped Chtamalus spp. and thus the species was defined "mostly carnivorous."

Apparently, fleshy algae are not a limited resource in the barren patches for $P$. lividus as they constitute the bulk of the diet in this species (as observed in both gut contents and stable isotope analysis). Accordingly, the reproductive condition (GSI) of P. lividus was not affected by the state. This finding is in agreement with Chiantore et al., 2008. In that study, the GSI of P. lividus was similar in barren and forest states. A likely explanation is that drifting fragments of fleshy algae can be captured by P. lividus even when it is residing in barren patches. Actually, this "drift-trapping behaviour" was observed in other sea urchin species occurring in areas where erect algae abundance is low (Vanderklift and Wernberg, 2008). Besides drift algae, sediment or re-suspended organic material could also be caught by $P$. lividus with its sulcated spines and numerous aboral tube feet (Régis, 1978). This scenario is supported by the values of SOM assimilated by this species (18\%). Moreover, the fact that leathery macrophyte were largely ingested but not assimilated by $P$. lividus in forests could indicate a "mower" activity of this species, aimed at easily reaching its preferred food (i.e. soft algae) or creating a suitable patch where it can better attach (Gianguzza et al., 2010) and feed

\section{Table 6}

Results of ANCOVA testing for differences in sea urchin GSI considering the fixed factor "State" with two levels (barren and forest) and the random factor "Patch" (Pa) nested in "State" with two levels $\left(\mathrm{P}_{1}\right.$ and $\left.\mathrm{P}_{2}\right)$ considering the sea urchins total weight as covariate.

\begin{tabular}{lllllll}
\hline Source & $d f$ & MS & Pseudo- $F$ & $P($ perm $)$ & Unique perms & $P(\mathrm{MC})$ \\
\hline $\begin{array}{l}\text { A. lixula } \\
\text { Tot wet weight }\end{array}$ & 1 & 0.62 & $33,699.00$ & 0.16 & 9848 & 0.15 \\
$\quad($ To $)$ & & & & & & \\
State (St) & 1 & $25,629.00$ & $13,024.00$ & 0.00 & 24 & 0.07 \\
Patch (Pa) (St) & 2 & 0.15 & 0.35 & 0.71 & 9946 & 0.72 \\
To $\times$ St & 1 & 32.04 & 75.59 & 0.93 & 9833 & 0.93 \\
To $\times$ Pa (St) & 2 & 0.99 & $23,309.00$ & 0.13 & 9947 & 0.14 \\
Res & 12 & 0.42 & & & & \\
Total & 19 & & & & & \\
& & & & & & \\
$P$. lividus & & & & & & \\
Tot wet weight & 1 & $15,846.00$ & $30,241.00$ & 0.12 & 9836.00 & 0.19 \\
$\quad($ To $)$ & & & & & & \\
State (St) & 1 & 962.13 & 13.61 & 1.00 & 24.00 & 0.98 \\
Patch (Pa) (St) & 2 & $93,623.00$ & $66,499.00$ & 0.01 & 9963.00 & 0.01 \\
To $\times$ St & 1 & $10,988.00$ & 0.78 & 0.39 & 9823.00 & 0.39 \\
To $\times$ Pa (St) & 2 & $24,147.00$ & $17,151.00$ & 0.22 & 9950.00 & 0.23 \\
Res & 12 & $14,079.00$ & & & & \\
Total & 19 & & & & & \\
\hline
\end{tabular}


on delivered material. There are at least two main reasons explaining why A. lixula prefers the barren patches: (a) this species cannot move in forest as fast as P. lividus (i.e. reduced movement ability) and (b) endolithic species, associated to encrusting algae, are abundant only in the barren. Notably, in volcanic basaltic substrates, such as our case study area, endolithic fauna mainly occurs at the expense of calcareous organisms. In particular, it was recently observed that the biomass of sipunculids living under coralline hypostrata appears to be very high in the Ustica barren (Badalamenti personal observations). A recent work conducted in the shallow subtidal zone of the Auletians Islands revealed that barrens support a rich cryptic invertebrate community, composed mainly of spionids and sipunculids (Chenelot et al., 2011). It was proposed that encrusting algae form several crevices, cavities, interstices colonized by bryozoans, polychaetes, echiurans, molluscs and ophiuroids. In addition, Ojeda and Deaborn (1989) and Taylor (1988) also observed that crustose coralline communities support a high diversity of species and sustain high secondary productivity. In this context, it could be suggested that the Aristotle's lantern of $A$. lixula, larger than that of $P$. lividus and able to scrape off corallines and consume benthic organisms, could be considered an evolutive adaptation to durophagy (Hagen, 2008).

Overall, our results suggest a dynamic scenario during state transition from forest to barren in mosaic patches. Initially, P. lividus may find sufficient food in the barren state (e.g. drift algae, SOM) (result of the present study, Chiantore et al., 2008). However, when the abundance of this species increases, it may suffer intra-specific competition (Privitera et al., 2008). This may lead to a behavioral switch from passive feeding in barren patches to active grazing in forest patches, where P. lividus can penetrate to obtain food (results of the present study, Kempf, 1962; Verlaque, 1987; Sala and Zabala, 1996). By consuming and removing the erect algae canopy, P. lividus prepares a bare space, which is then colonized by encrusting algae and its associated "cryptic fauna." At this point A. lixula, which settles preferentially in encrusting coralline algae, can colonize the barren (Privitera et al., 2011) and maintain it (Bulleri et al., 1999, Bonaviri et al., 2011). According to this facilitative model, and in contrast to the traditional hypothesis of a competitive scenario, the decrease of $P$. lividus recorded in recent years at Ustica MPA did not trigger any increase in A. lixula (Agnetta et al., 2010; Bonaviri et al., 2009; Gianguzza et al., 2006). Our results suggest that the expansion of the barren state may be driven by facilitation processes (Bruno et al., 2003; Duggins, 1981) between the two co-occurring sea urchins. Interestingly, our results indicate that the barren does not seem to be a poor and unproductive system. More research, on larger spatial and time scales, is needed to confirm the findings shown here, and overall to better understand the general functioning of the barren ecosystem. This would provide useful data for the effective management of Mediterranean rocky reef.

\section{Acknowledgements}

The authors are indebted to Francesco Di Trapani for his help during field work. They greatly thank Tomás Vega Fernández for his suggestions for the data analysis and Giovanni Fanelli for his helpful comments on this research. This study was funded by the M.A.T.T.M. (Ministero dell'Ambiente Difesa del Territorio e del Mare) research project "Monitoraggio delle popolazioni di P. lividus e A. lixula ai fini della tutela della diversità biologica dell'AMP "Isola di Ustica." The authors are indebted to Julie-Anne Buck for revising the English text.

\section{Appendix A. Supplementary data}

Supplementary data to this article can be found online at http:// dx.doi.org/10.1016/j.seares.2012.08.009.

\section{References}

Agatsuma, Y., Nakabayashi, N., Miura, N., Taniguchi, K., 2005. Growth and gonad production of the sea urchin Hemicentrotus pulcherrimus in the fucoid bed and algal turf in northern Japan. Marine Ecology 26, 100-109.

Agnetta, D., Bonaviri, C., Gianguzza, P., Riggio, S., 2010. The MPA “Isola di Ustica”: a model of benthic community natural changes. Biologia Marina Mediterranea 17 (1), 120-121.

Anderson, M.J., 2001. A new method for non-parametric multivariate analysis of variance. Austral Ecology 26, 32-46 http://dx.doi.org/10.1111/j.1442-9993.2001.01070.pp.x.

Arafa, S., Sadok, S., El Abed, A., 2006. Variation in nitrogenous compounds and gonad index in fed and starved sea urchins (Paracentrotus lividus) during live storage. Aquaculture 257, 525-533.

Bayed, A., Quiniou, F., Benrha, A., Guillou, M., 2005. The Paracentrotus lividus populations from the northern Moroccan Atlantic coast: growth, reproduction and health condition. Journal of the Marine Biological Association of the United Kingdom 85, 999-1007.

Beisner, B.E., Haydon, D.T., Cuddington, K., 2003. Alternative stable states in ecology. Frontiers in Ecology and the Environment 1 (7), 376-382.

Benedetti-Cecchi, L., Cinelli, F., 1995. Habitat heterogeneity, sea urchin grazing and the distribution of algae in littoral rock pools on the west coast of Italy (western Mediterranean). Marine Ecology Progress Series 126, 203-212 http://dx.doi.org/ 10.3354/meps126203.

Benedetti-Cecchi, L., Bulleri, F., Cinelli, F., 1998. Density dependent foraging of sea urchins in shallow subtidal reefs on the west coast of Italy (western Mediterranean). Marine Ecology Progress Series 163, 203-211 http://dx.doi.org/10.3354/meps163203.

Bonaviri, C., Fernandez, T.V., Badalamenti, F., Gianguzza, P., Di Lorenzo, M., Riggio, S. 2009. Fish versus starfish predation in controlling sea urchins populations in Mediterranean rocky shores. Marine Ecology Progress Series 382, 129-138.

Bonaviri, C., Vega Fernández, T., Fanelli, G., Badalamenti, F., Gianguzza, P., 2011. Leading role of sea urchin Arbacia lixula in maintaining barren state in southwestern Mediterranean. Marine Biology 158, 2505-2513 http://dx doi.org/10.1007/s00227-011-1751-2.

Brady, S.M., Scheibling, R.E., 2006. Changes in growth and reproduction of green sea urchins, Strongylocentrotus droebachiensis (Müller), during repopulation of the shallow subtidal zone after mass mortality. Journal of Experimental Marine Biology and Ecology 335, 277-291.

Brewin, P.E., Lamare, M.D., Keogh, J.A., Mladenov, P.V., 2000. Reproductive variability over a four year period in the sea urchin Evechinus chloroticus (Echinoidea:Echinodermata) from differing habitats in New Zeland. Marine Biology 137, 543-557.

Bruno, J.F., Stachowicz, J.J., Bertness, M.D., 2003. Inclusion of facilitation into ecological theory. Trees 18 (3), 119-125.

Bulleri, F., Benedetti-Cecchi, L., 2006. Mechanisms of recovery and resilience of different components of mosaics of habitats on shallow rocky reefs. Oecologia 149, 482-492 http://dx.doi.org/10.1007/s00442-006-0459-3.

Bulleri, F., Benedetti-Cecchi, L., Cinelli, F., 1999. Grazing by the sea urchins Arbacia lixula L. and Paracentrotus lividus Lam. in the Northwest Mediterranean. Journal of Experimental Marine Biology and Ecology 241, 81-95 http://dx.doi.org/10.1016/S00220981(99)00073-8.

Byrne, M., 1990. Annual reproductive cycles of the commercial sea urchin Paracentrotus lividus from an exposed intertidal and a sheltered subtidal habitat on the west coast of Ireland. Marine Biology 104, 275-289.

Cabral de Oliveira, M., 1991. Survival of seaweeds ingested by three species of tropical sea urchins from Brazil. Hydrobiologia 222, 13-17.

Cardona, L., Sales, M., Lopez, D., 2007. Changes in fish abundance do not cascade to sea urchins and erect algae in one of the most oligotrophic parts of the Mediterranean. Estuarine, Coastal and Shelf Science 72, 273-282.

Chenelot, H., Jewett, S.C., Hoberg, M.K., 2011. Macrobenthos of the nearshore Aleutian Archipelago, with emphasis on invertebrates associated with Clathromorphum nereostratum (Rhodophyta, Corallinaceae). Marine Biodiversity 41, 413-424 http://dx.doi.org/10.1007/s12526-010-0071-y.

Chiantore, M., Vielmini, I., Privitera, D., Mangialajo, L., Cattaneo-Vietti, R., 2008. Habitat effect on the population structure of Paracentrotus lividus and Arbacia lixula. Chemistry and Ecology 54 (S1), 145-157.

Coleman, M.A., Kelaher, B.P., Steinberg, P.D., Millar, A.J.K., 2008. Absence of a large brown macroalga on urbanized rocky reefs around Sydney, Australia, and evidence for historical decline. Journal of Phycology 44, 897-901.

Di Trapani, 2011. Interazioni e trofodinamica della megafauna bentonica associata a due stati stabili alternativi dell'infralitorale superiore roccioso del mediterraneo. Phd thesis. University of Palermo.

Duggins, D.O., 1981. Interspecific facilitation in a guild of benthic marine herbivores Oecologia 48, 157-163.

Ebert, T.A., Hernandez, J.C., Russell, M.P., 2011. Problems of the gonad index and what can be done: analysis of the purple sea urchin Strongylocentrotus purpuratus Marine Biology 158, 47-58 http://dx.doi.org/10.1007/s00227-010-1541-2.

Fanelli, G., Piraino, S., Belmonte, G., Geraci, S., Boero, F., 1994. Human predation along Apulian rocky coasts (SE Italy) - Desertification caused by Lithophaga lithophaga (Mollusca) fisheries (1994) Marine Ecology Progress Series, 110 (1), pp. 1-8.

Fernandez, C., Boudouresque, C.F., 1997. Phenotypic plasticity of Paracentrotus lividus (Echinodermata: Echinoidea) in a lagoonal environment. Marine Ecology Progress Series 152, 145-154 http://dx.doi.org/10.3354/meps152145.

Fernandez, C., Boudouresque, C.F., 2000. Nutrition of the sea urchin Paracentrotus lividus (Echinodermata: Echinoidea) fed different artificial food. Marine Ecology Progress Series 204, 131-141.

Frantzis, A., Gremare, A., 1992. Ingestion, absorption, and growth rates of Paracentrotus lividus (Echinodermata: Echinoidea) fed different macrophytes. Marine Ecology Progress Series 95, 169-183.

Ganteaume, A., Gobert, J., Malestroit, P., Ménager, V., Francour, P., Boudouresque, C.F. 1998. In vitro consumption of Caulerpa taxifolia (Chlorophyta) by accustomed 
and non-accustomed Paracentrotus lividus (Echinoid): seasonal variations. Journal of the Marine Biological Association of the United Kingdom 78, 239-248 http:// dx.doi.org/10.1017/S0025315400040066.

Gianguzza, P., Chiantore, M., Bonaviri, C., Cattaneo-Vietti, R., Vielmini, I., Riggio, S. 2006. The effects of recreational Paracentrotus lividus fishing on distribution patterns of sea urchins at Ustica Island MPA (Western Mediterranean, Italy). Fisheries Research 81, 37-44 http://dx.doi.org/10.1016/j.fishres.2006.06.002.

Gianguzza, P., Badalamenti, F., Bonaviri, C., Riggio, S., 2009a. The operational sex ratio of the sea urchins Paracentrotus lividus population: the case of the Mediterranean marine protected area of Ustica Island (Tyrrhenian Sea Italy). Marine Ecology 30, 125-132.

Gianguzza, P., Bonaviri, C., Guidetti, P., 2009b. Crushing predation of the spiny sta Marthasterias glacialis upon the sea urchin Paracentrotus lividus. Marine Biology (Heidelberg, Germany) 156, 1083-1086.

Gianguzza, P., Bonaviri, C., Milisenda, G., Barcellona, A., Agnetta, D., Vega Fernàndez, T. Badalamenti, F., 2010. Macroalgal assemblage type affects predation pressure on sea urchins by altering adhesion strength. Marine Environment Research 70, 82-86.

Gianguzza, P., Agnetta, D., Bonaviri, C., Di Trapani, F., Visconti, G., Gianguzza, F., Riggio S., 2011. The rise of thermophilic sea urchins and the expansion of barren grounds in the Mediterranean Sea. Chemistry and Ecology 27, 129-134.

Graham, M., 2004. Effects of local deforestation on the diversity and structure of Southern California Giant Kelp forest food webs. Ecosystems 7, 341-357.

Guidetti, P., 2006. Marine reserves reestablish lost predatory interactions and cause community changes in rocky reefs. Ecological Applications 16, 963-976 http:// dx.doi.org/10.1890/1051-0761(2006) 016[0963:MRRLPI]2.0.CO;2.

Guidetti, P., Dulčić, J., 2007. Relationship among predatory fish, sea urchins and barrens in Mediterranean rocky reefs across a latitudinal gradient. Marine Environmenta Research 63, 168-184 http://dx.doi.org/10.1016/j.marenvres.2006.08.002.

Guidetti, P., Mori, M., 2005. Morpho-functional defences of Mediterranean sea urchins, Paracentrotus lividus and Arbacia lixula, against fish predators. Marine Biology 147, 797-802.

Hagen, N.T., 2008. Enlarged lantern size in similar-sized, sympatric, sibling species of Strongylocentrotid sea urchins: from phenotypic accommodation to functional adaptation for durophagy. Marine Biology 153, 907-924.

Hereu, B., 2006. Depletion of palatable algae by sea urchins and fishes in a Mediterranean subtidal community. Marine Ecology Progress Series 313, 95-103 http:// dx.doi.org/10.3354/meps313095.

Hereu, B., Zabala, M., Sala, E., 2008. Multiple controls of community structure and dynamics in a sublittoral marine environment. Ecology 89, 3423-3435.

Hobson, K.A., Welch, H.E., 1992. Determination of trophic relationships within a high Arctic marine food web using $\delta^{13} \mathrm{C}$ and $\delta^{15} \mathrm{~N}$ analysis. Marine Ecology Progress Series 84, 9-18.

Jackson, J.B.C., 1979. Morphological strategies of sessile animals. In: Larwood, G., Rosen, B. (Eds.), Biology and Systematics of Colonial Animals. Academic Press, London, pp. 499-556.

Kempf, M., 1962. Recherchs d'ècologie comparée sur Paracentrotus lividus (Lmk.) et Arbacia lixula (L.). Recueil des Travaux de la Station Marine d'Endoume Faculte des Sciences de Marseille 25, 47-116.

Knoepffler-Peguy, M., Maggiore, F., Boudouresque, C.F., Dance, C., 1987. Compte-rendu sur les preferanda alimentaires de Paracentrotus lividus (Echinoidea) à Banyuls sur mer. France. In: Boudouresque, C.F. (Ed.), Colloque international sur Paracentrotus lividus et les oursins commestibles. GIS Podidonie Publications, Marseille, pp. 59-64.

Knowlton, N., 2004. Multiple "stable" states and the conservation of marine ecosystems. Progress in Oceanography 60, 387-396 http://dx.doi.org/10.1016/j.pocean.2004.02.011.

Konar, B., Estes, J.A., 2003. The stability of boundary regions between kelp beds and deforested areas. Ecology 84 (1), 174-185 http://dx.doi.org/10.1890/00129658(2003) 084[0174:TSOBRB]2.0.CO;2]

Levitan, D.R., 1991. Skeletal changes in the test and jaws of the sea urchin Diadema antillarum in response to food limitation. Marine Biology 111, 431-435.

Levitan, D.R., 1992. Community structure in time past: influence of human fishing on algal-urchin interactions. Ecology 73, 1597-1605.

McCutchan Jr., J.H., Lewis Jr., W.M., Kendall, C., McGrath, C.C., 2003. Variation in trophic shift for stable isotope ratios of carbon, nitrogen, and sulfur. Oikos 102, 378-390.

Micheli, F., Benedetti-Cecchi, L., Gambaccini, S., Bertocci, I., Borsini, C., Chato Osio, G., Romano, F., 2005. Cascading human impacts, marine protected areas, and the structure of Mediterranean reef assemblages. Ecological Monographs 75, 81-102 http://dx.doi.org/10.1890/03-4058.

Ojeda, F.P., Deaborn, J.H., 1989. Community structure of macroinvertebrates inhabiting the rocky subtidal zone in the Gulf of Maine: seasonal and bathymetric distribution. Marine Ecology Progress Series 57, 147-161.

Otero-Villanueva, M., Kelly, M.S., Burnell, G., 2004. How diet influences energy partitioning in the regular echinoid Psammechinus miliaris; costructing an energy budget. Journal of Experimental Marine Biology and Ecology 304, 159-181.

Palumbi, S.R., McLeod, K.L., Grümbaum, D., 2008. Ecosystem in action: lessons from marine ecology about recovery, resistance and reversibility. Bioscience 58, 33-42.

Penchaszadeh, P., 1979. Estructura de la comunidad y procesos que la determinan en bancos circalitorales de mejillon Mytilus platensis. Memorias del seminario sobre ecologia bentonica y sedimentacion de la plataforma continental del Atlantico Sur. UNESCO, Montevideo, pp. 131-145.
Phillips, D.L., Gregg, J.W., 2003. Source partitioning using stable isotopes: coping with too many sources. Oecologia 136, 261-269.

Privitera, D., Chiantore, M., Mangialajo, L., Glavic, N., Kozul, W., Cattaneo-Vietti, R., 2008. Inter- and intra-specific competition between Paracentrotus lividus and Arbacia lixula in resource-limited barren areas. Journal of Sea Research 60, 184-192 http://dx.doi.org/10.1016/j.seares.2008.07.001.

Privitera, D., Noli, M., Falugi, C., Chiantore, M., 2011. Benthic assemblages and temperature effects on Paracentrotus lividus and Arbacia lixula larvae and settlement. Journal of Experimental Marine Biology and Ecology 407, 6-11 http://dx.doi.org/ 10.1016/j.jembe.2011.06.030.

Régis, M.B., 1978. Croissance de deux échinoïdes du golfe de Marseille (Paracentrotus lividus (Lmck) et Arbacia lixula L.). Aspects écologiques de la micrsotructure du squelette et de l'évolution des indices physiologiques. Thèse Doct Sci, Univ AixMarseille III.

Riggio, S., Milazzo, M., 2004. Ricchezza specifica e biodiversità marina nell'isola di Ustica. Naturalista Siciliano 28, 559-586.

Sala, E., Zabala, M., 1996. Fish predation and the structure of the sea urchin Paracentrotus lividus populations in the NW Mediterranean. Marine Ecology Progress Series 140, 71-81 http://dx.doi.org/10.3354/meps140071.

Sala, E., Boudouresque, C.F., Harmelin-Vivien, M., 1998. Fishing, trophic cascades, and the structure of algal assemblages: evaluation of an old but untested paradigm. Oikos 82, 425-439.

Sala, E., Ballesteros, E., Dendrinos, P., Di Franco, A., Ferretti, F., et al., 2012. The structure of Mediterranean rocky reef ecosystems across environmental and human gradients, and conservation implications. PloS One 7 (2), e32742 http://dx.doi.org/ 10.1371/journal.pone.0032742.

Sànchez-España, A.I., Martìnez-Pita, I., Garcìa, F.J., 2004. Gonadal growth and reproduction in the commercial sea urchin Paracentrotus lividus (Lamarck, 1816) (Echinodermata: Echinoidea) from southern Spain. Hydrobiologia 519, 61-72.

Santos, R., Flammang, P., 2005. Morphometry and mechanical design of tube foot stems in sea urchins: a comparative study. Journal of Experimental Marine Biology and Ecology 315, 211-223.

Santos, R., Flammang, P., 2007. Intra- and interspecific variation of attachment strength in sea urchins. Marine Ecology Progress Series 332, 129-142.

Scheffer, M., Carpenter, S., Foley, J.A., Folke, C., Walker, B., 2001. Catastrophic shifts in ecosystems. Nature 413, 591-596.

Silva, J., Larrain, A., Bay-Schmith, E., Roa, R., 2004. Feeding-regime experiments to enhance gamete production in the carnivorous Sea Urchin Arbacia spatuligera. Aquaculture 231, 279-291.

Steneck, R.S., Dethier, M.N., 1994. A functional group approach to the structure of algaldominated communities. Oikos 69, 476-498.

Steneck, R.S., Graham, M.H., Bourque, B.J., Corbett, D., Erlandson, J.M., Estes, J.A., Tegner, M.J., 2002. Kelp forest ecosystems: biodiversity, stability, resilience and future. Environmental Conservation 29, 436-459.

Suding, K.N., Gross, K.L., Houseman, G.R., 2004. Alternative states and positive feedbacks in restoration ecology. Trends in Ecology \& Evolution 19 (1), 46-53.

Sunseri, G., 1995. Studio sulle caratteristiche granulometriche, la distribuzione di metalli in traccia e l'attività batterica nei sedimenti dei fondali della riserva naturale marina "isola di Ustica". Final report ICRAM RNM Isola di Ustica Ministero dell'ambiente, p. 49.

Taylor, R.B., 1988. Density, biomass and productivity of animals in four subtidal rocky reef habitats: the importance of small mobile invertebrates. Marine Ecology Progress Series 172, 37-51.

Tomas, F., Álvarez-Cascos, D., Turon, X., Romero, J., 2006. Differential element assimilation by sea urchins Paracentrotus lividus in seagrass beds: implications for trophic interactions. Marine Ecology Progress Series 306, 125-131.

Underwood, A.J., 1997. Experiments in ecology: their logical design and interpretation using analysis of variances. Cambridge University Press, Cambridge.

Vanderklift, M.A., Wernberg, T., 2008. Detached kelps from distant sources are a food subsidy for sea urchins. Oecologia 157, 327-335 http://dx.doi.org/10.1007/ s00442-008-1061-7.

Vanderklift, M.A., Kendrick, G.A., Smitm, A.J., 2006. Differences in trophic position among sympatric sea urchin species. Estuarine, Coastal and Shelf Science 66, 291-297.

Verlaque, M., 1987. Relations entre Paracentrotus lividus (Lamarck) et le phytobenthos de Mediterranee occidentale. In: Boudoresque, C.F. (Ed.), Colloque International sur Paracentrotus lividus et les oursins comestibles. GIS Posidonie Publication, Marseille, pp. 5-36.

Wangensteen, O.S., Turón, X., García-Cisneros, A., Recasens, M., Romero, J., Palacín, C., 2011. A wolf in sheep's clothing: carnivory in dominant sea urchins in the Mediterranean. Marine Ecology Progress Series 441, 117-128 http://dx.doi.org/10.3354/ meps09359.

Watson, J., Estes, J., 2011. Stability, resilience, and phase shifts in rocky subtidal communities along the west coast of Vancouver Island, Canada. Ecological Monographs 81 (2), 215-239.

Winer, B.J., Brown, D.R., Michels, K.M., 1991. Statistical principles in experimental designs, 3rd ed. McGraw-Hill, Sydney. 